\title{
REVIEW
}

\section{Critical role of toll-like receptors and nucleotide oligomerisation domain in the regulation of health and disease}

\author{
Jane A Mitchell, Mark J Paul-Clark, Graham W Clarke, Shaun K McMaster and Neil Cartwright \\ Cardiothoracic Pharmacology, Unit of Critical Care Medicine, Cardiac Medicine, Royal Brompton Hospital, National Heart and Lung Institute, Imperial College, \\ London SW3 6LY, UK \\ (Requests for offprints should be addressed to J A Mitchel; Email: j.a.mitchell@imperial.ac.uk)
}

\begin{abstract}
Pathogens are sensed by pattern recognition receptors (PRRs), which are germ line-encoded receptors, including transmembrane Toll-like receptors (TLRs) and cytosolic nucleotide oligomerisation domain (NOD) proteins, containing leucine-rich repeats (NLRs). Activation of PRRs by specific pathogen-associated molecular patterns (PAMPs) results in genomic responses in host cells involving activation transcription factors and the induction of genes. There are now at least 10 TLRs in humans and 13 in mice, and 2 NLRs (NOD1 and NOD2). TLR signalling is via interactions with adaptor proteins including MyD88 and tollreceptor associated activator of interferon (TRIF). NOD

signalling is via the inflammasome and involves activation of Rip-like interactive clarp kinase (RICK). Bacterial lipopolysaccharide (LPS) from Gram-negative bacteria is the beststudied PAMP and is activated by or 'sensed' by TLR4. Lipoteichoic acid (LTA) from Gram-positive bacteria is sensed by TLR 2 . TLR 4 and TLR 2 have different signalling cascades, although activation of either results in symptoms of sepsis and shock. This review describes the rapidly expanding field of pathogen-sensing receptors and uses LPS and LTA as examples of how these pathways parallel and diverge from each other. The role of pathogen-sensing pathways in disease is also discussed. Journal of Endocrinology (2007) 193, 323-330
\end{abstract}

\section{Introduction}

In humans and other mammals, innate immune responses provide the first line of defence against invading bacterial pathogens. Pathogen-associated molecular patterns (PAMPs) such as lipopolysaccharide (LPS) from Gram-negative bacteria or lipoteichoic acid (LTA) from Gram-positive bacteria are sensed by macrophages and other immune cells to produce an acute response to the pathogens. Our knowledge of how cells of the immune system sense and respond to a pathogen has increased dramatically within the past few years. Pathogens have specific molecular patterns within their structures, referred to as PAMPs (Fig. 1). Cells of the immune system are activated by, or 'sensed' by, pathogens via pathogen-sensing receptors, also known as pattern recognition receptors (PRRs). PRRs are germ line-encoded receptors that sense specific PAMPs and activate responses in cells. These responses are usually genomic involving the induction of new genes via well-classified transduction pathways including NFKB and AP-1. PRRs include transmembrane toll-like receptors (TLRs) and cytosolic nucleotide oligomerisation domain (NOD) proteins containing leucine-rich repeats (NLRs).

\section{Bacterial LPS and its effects on biological systems}

Bacterial LPS from the cell wall of Gram-negative bacteria has been used in the study of inflammation and the regulation of 'inducible genes' for decades. Its efficacy as a model of inflammation means that it is used by scientists in many fields of biomedical research. Indeed, LPS is more often used as a model of 'inflammation' than innate immunity. Many of the researchers, who use LPS, rarely gave much attention to how it may be sensed at the surface of the cells being studied. However, a complex interaction between TLR4 and other proteins and factors result in the sensing of LPS by cells. First, we shall consider the effects of LPS in vitro and in vivo, which would explain why it is very useful as a model of inflammation. LPS mimics many inflammatory effects of cytokines, particularly TNF $\alpha$, interleukin- $1 \beta$ (IL-1 $\beta$ ) or IL-6. However, LPS has several advantages over cytokines: it is inexpensive, it is not restricted by species differences and it generally provides a more robust response than individual cytokines.

When administered to cells in vitro, LPS induces a plethora of inflammatory and vasoactive genes, including nitric oxide synthase (NOS)II, cyclo-oxygenase-2, endothelin-1, TNF 




Figure 1 Relationship between pathogen-associated molecular patterns (PAMPs), pattern recognition receptors (PRRs) and pathogens. Toll-like receptor (TLR), lipoteichoic acid (LTA), lipopolysaccharide (LPS), double-stranded (ds), single-stranded (ss) RNA, peptidoglycan (PepG).

and other cytokines. When LPS is administered i.v. in vivo, it induces a profound shock (Maclean \& Weil 1956). The type of shock induced by LPS is striking. There is an initial drop in blood pressure which begins within 5 min of injection, but resolves within $30-60 \mathrm{~min}$. This is followed after several hours, by a later phase shock characterised by a decline in blood pressure, which is resistant to vasoconstrictors (Szabo et al. 1993). The later phase shock is associated specifically with the induction of NOSII in the vascular smooth muscle component of blood vessels (Szabo et al. 1993, Bishop-Bailey et al. 1997). When LPS is injected locally into the peritoneal cavity (Ajuebor et al. 1999, Elmali et al. 2007), foot pads (Cunha et al. 2000), brain (Marchalant et al. 2007) or inhaled into the lungs (Haddad et al. 2002), an inflammatory response is induced which is generally typified by the activation of macrophages and early recruitment of neutrophils. As explained above, for many years, the signalling pathways involved in the actual sensing of the LPS were unknown. However, it was known that the sensing of LPS was greatly enhanced by the presence of serum, and the serum elements were LPS-binding protein (LBP) and CD14.

\section{LBP and CD14}

It was originally believed that LPS activated immune cells through a non-specific mechanism that involved the spontaneous intercalation of lipid A into the mammalian lipid bilayer. However, in the early 1980s, reports emerged suggesting that the biological actions of LPS were facilitated many fold by its binding to endogenous proteins. Tobias et al. (1986) identified LBP (Zweigner et al. 2006). LBP binds to the amphipathic lipid A moiety of LPS (Schumann et al. 1990) and facilitates its presentation and transfer to CD14. In 1990, CD14 was first identified as important to
LPS sensing when Wright et al. (1990) demonstrated that it acted as a cell surface 'receptor' for the LPS-LBP complex. Initially, and for some years, CD14 was thought to be the actual transducing receptor for the LPS. However, CD14 acts as a manoeuvring protein to guide the complex to TLR4 (see below; Fig. 2).

\section{Identification and elucidation of the role of TLR4}

In the early 1980 s, the understanding of TLR-signalling was emerging from fields separate to that of LPS biology. In 1985 , a mutant Drosophila that had an unusual appearance was described (Anderson et al. 1985) and was named 'Toll', which means 'weird'. This was caused by a mutation in the Toll gene, which encodes a single-pass transmembrane receptor. In addition to controlling certain developmental processes, toll mediates immunity in flies to fungal and Gram-positive bacteria infections (Gay \& Keith 1991, Belvin \& Anderson 1996, Lemaitre et al. 1996, Imler \& Hoffmann 2001) and was noted to share certain homology with the human IL-1 receptor (Gay \& Keith 1991). In the mid-1990s, the field of Toll biology moved beyond flies when several groups identified areas in mammalian gene sequences encoding proteins homologous to toll (Taguchi et al. 1996, Medzhitov et al. 1997, Rock et al. 1998). In another seminal publication, Medzhitov et al. (1997) showed that activation of a human TLR leads to activation of transcription factor NFKB and elements of innate immune responses (Medzhitov et al. 1997).

As mentioned above, LPS is a very active mediator of inflammation in most mammalian systems. However, it has been known for many years that some strains of mice are unresponsive to LPS. For example, LPS is relatively ineffective at inducing responses in the $\mathrm{C} 3 \mathrm{H} / \mathrm{HeJ}$ or $\mathrm{C} 57 \mathrm{BL} / 10 \mathrm{ScCr}$ strains of mouse (Skidmore et al. 1975). Poltorak et al. 1998 showed using positional cloning techniques that mutations of a gene termed the 'Lps gene' selectively reduced the ability of $\mathrm{C} 3 \mathrm{H} / \mathrm{HeJ}$ and $\mathrm{C} 57 \mathrm{BL} / 10 \mathrm{ScCr}$ mice to sense LPS. The mutation was shown to correspond to a missense mutation in the third exon of the TLR-4 gene (Poltorak et al. 1998). A similar conclusion was made in 1999 by the Akiras group (Hoshino et al. 1999) who also showed that C3H/HeJ mice have a single point mutation of the amino acid that is conserved among the IL-1/Toll receptor family. They showed, using genetically modified mice in which TLR 4 had been deleted, that TLR 4 was essential for the sensing of LPS and that its lack of function explained the lack of responsiveness seen in $\mathrm{C} 3 \mathrm{H} / \mathrm{HeJ}$ mice. Since the publication of these two seminal papers, there has been a large expansion in our understanding of how TLR 4 functions in immune responses to LPS, as well as to disease processes without any apparent pathogen link. This may well be due to the fact that TLR 4 can not only act as a receptor for LPS, but also for a number of host-derived ligands. 




Figure 2 Signalling pathways employed by RLE2 and TLR4. LPS from Gram-negative bacteria, such as Escherichia coli, is manoeuvred to MD2 forming a complex that activates TLR4. The TLR-IL-1 receptor (TIR) domains of TLR4 and TRIF or MyD88 are engaged and signalling occurs via the MyD88 or TRIF pathways leading to NOSII or TNF1 respectively. LTA from Gram-positive bacteria such as Staphylococcus aureus or diacylated lipoproteins are guided by CD36 to activate the TLR2/TLR6 complex. Triacylated lipoproteins activate the TLR2/TLR1 heterodimer. Once activated the TIR domain of TLR2 engages with the TIR domain of MyD88 leading to the induction of 'MyD88-dependent' genes including TNF $\alpha$. Synergy is often seen between TLR and NOD signalling pathways.

\section{Relationship between CD14, TLR4 and MD2}

It is known that MD 2 is required for TLR4 signal transduction. MD 2, like CD14, can be cell bound or secreted and provided to non MD2-bearing cells in serum (Schromm et al. 2001, Fitzgerald et al. 2004). In cells, MD2 is bound to TLR4 (Visintin et al. 2001, Fitzgerald et al. 2004) where it greatly enhances the sensing of LPS (Shimazu et al. 1999). It is believed that MD2 complexes with LPS (provided by CD14) and that the MD2-LPS complex, as apposed to LPS alone, is the 'true ligand' for TLR4 (Fitzgerald et al. 2004, Mitchell et al. 2006). However, the precise relationship between TLR4 and MD2 in all instances remains the subject of investigation.

\section{TLRs as a complex family of receptors}

By 1998, five human TLR homologues had been identified (Rock et al. 1998). There are now at least 10 TLRs in humans and 13 in mice (West et al. 2006). Both humans and mice have TLRs 1-9. TLR10 is only found in humans, whereas TLR11 is only found in mice. Pathogen ligands (PAMPs) have been identified for TLRs 1-9 (Fig. 1), but the ligands and functions of TLRs 10-13 are less well understood. All of the TLRs contain a TLR-IL-1 receptor (TIR) domain that engages with a TIR domain on one of the number of adaptor proteins. There are two well-defined TLR signalling pathways mediated respectively by MyD88 or TRIF adaptor proteins. MyD88-dependent signalling is common to all of the TLRs, except for TLR3. It involves early phase activation of NFKB via the IL-1R-associated kinase (IRAK) pathway. MyD88-independent signalling is via TRIF and is utilised by TLR 4 and TLR 3. It is mediated by an interferon regulatory factor 3 pathway, which results in a later phase activation of NFKB. Mal acts as an anchor protein between MyD88 and TIR domains, and may also have a direct role in signalling via interactions with tumour necrosis factor receptor-associated factor 6 (Mansell et al. 2004). Like Mal for MyD88, TRAM seems to link TRIF with the intracellular regions of TLR4. Separate banks of response genes are induced by the MyD88 and TRIF pathways. Importantly, TNF $\alpha$ is a MyD88dependent gene whereas interferon (IFN) is classified as MyD88 independent, and therefore TRIF dependent (Toshchakov et al. 2002). A list of some of the known ligands for different TLRs is shown in Fig. 1 and the specificities of TLR1, 2, 4 and 6 are discussed in detail below. TLR 5 is a cell surface receptor activated by flagellin, a protein expressed on motile bacteria (Gewirtz et al. 2001, Hayashi et al. 2001). TLR3 is an intracellular receptor which is activated by viral 
double-stranded RNA; TLR7 and TLR 8 are activated by single-stranded RNA from viruses. TLR9 is activated by bacterial DNA, which because of its high level of unmethylated $\mathrm{CpG}$ dinucleotides is distinct from mammalian DNA (Hemmi et al. 2000). However, it is the sensing of bacterial wall components - LPS (from Gram-negative bacteria) and LTA (from Gram-positive bacteria) - that has been best studied and the differences that have been noted between these PAMPs in many ways define the level of sophistication and utility in the TLR and NOD pathways. As mentioned above, LPS from Gram-negative bacteria is sensed via TLR4. By contrast, LTA from Gram-positive bacteria is sensed by TLR2.

\section{TLR4 versus TLR2}

In many respects, LTA and LPS induce similar types of inflammatory responses. Like LPS, LTA will induce shock in laboratory animals (Lonchampt et al. 1992, Kengatharan et al. $1996 a, b)$ and NOSII in macrophages (Kengatharan et al. $1996 a, b)$. However, even if the end pathology may look the same in very broad terms, the signalling and sensing of LPS and LTA could not be more different. The importance of this is clear, when considering identification of new therapeutic targets (see below). As mentioned above, LPS is sensed by TLR 4. By contrast, LTA has no affinity for TLR 4, but activates TLR2 (Schwandner et al. 1999, Takeuchi et al. 1999a,b; Fig. 2). TLR4 and TLR 2 are both cell surface receptors. TLR 4 is unique among the TLRs because it recruits both MyD88/Mal and TRIF/TRAM adaptor proteins; TLR2, on the other hand, recruits just MyD88/Mal pathways. The current paradigm would suggest, therefore, that activation of TLR 4 allows for a more complex response, in that MyD88 and TRIFF pathways are both activated. However, TLR2 is not thought to act as a monomeric receptor (Triantafilou et al. 2006), but heterodimerises with either TLR1 (Ozinsky et al. 2000) or TLR6 (Takeuchi et al. 1999a,b) to evoke effects. LTA and diacylated fibroblast stimulating lipoprotein-1 (FSL-1) as well as triacylated ( $\left.\mathrm{Pam}_{3} \mathrm{CSK} 4\right)$ lipoproteins all evoke response via TLR2. In early reports, it was thought that TLR2 was the receptor for peptidoglycan (PepG). However, it is known that these observations were due to activation of TLR2 by contaminating lipoproteins in the PepG preparations and not PepG per se (Takeuchi et al. 2002, Travassos et al. 2004). Purified PepG activates NOD receptors.

Gram-positive bacteria contain LTA and lipoproteins. Lipoproteins can be either diacylated or triacylated. The TLR2/TLR6 complex is activated by LTA and diacylated lipoproteins, but not by triacylated lipoproteins (Takeuchi et al. 2001) while the TLR2/TLR1 complex is activated by triacylated lipoproteins, but not by diacylated lipoproteins. It is not yet clear what specific roles TLR2/TLR1 versus TLR2/TLR6 have in immune cells or in disease. Indeed, either complex engages the activation of MyD88-dependent genes and, at this level of signalling there is no clear evidence that the pathways diverge. However, for some ligands (LTA and R-MALP2), activation of the TLR2/TLR6 heterodimer is greatly facilitated by CD36 (Hoebe et al. 2005), which may act similarly to CD14 for TLR4. Interestingly, the level of complexity in pathogen sensing was further illustrated in a recent study by Triantafilou and co-workers showing that while CD36 facilitates TLR2/TLR6 signalling, CD14 enhanced the sensing of ligands by the TLR2/TLR 1 complex (Triantafilou et al. 2006).

\section{NOD receptors}

In addition to the TLRs, NOD proteins containing NLRs are critically involved in the sensing of bacterial pathogens (Fig. 3). NLRs have been shown to be PRRs for bacterial PepG. There are two well-defined NLRs, NOD1, also known as caspase recruitment domains (CARD4), and NOD2, also known as CARD15. NOD1 senses diaminopimelic acid (DAP)-containing PepG, which is mainly found in PepG of Gram-negative bacteria (Chamaillard et al. 2003), while NOD2 senses the muramyl dipeptide (MDP) present in both Gram-positive and Gram-negative PepG (Inohara et al. 2003). Both NOD1 and NOD2 signal via the adaptor protein RICK (also known as Rip2 or CARDIAK). RICK and NOD1 or NOD2 both contain (CARD) that interact to form a signalling platform comprised of a number of proteins collectively known as the inflammasome. The ensuing signalling cascade leads to activation of caspase- 1 and the formation of IL-1 $\beta$ and IL-8. (Inohara et al. 2005, Mariathasan \& Monack 2007). Synthetic NOD1 agonists stimulate chemokine production and neutrophil recruitment in vivo (Masumoto et al. 2006), but alone are ineffective in activating monocytic cells in vitro (van Heel et al. 2005). Because of the apparent lack of direct effects on cell signalling induced by activators of NLRs, it is suggested that their role in pathogen sensing is one of co-operation with the TLRs (Takada \& Uehara 2006). However, data from our group suggest that the actions of NOD1 vary between cell types and, unlike those seen with LPS, the in vivo effects may be independent of leukocyte activation. Specifically, we have shown that while selective activation of NOD1 in macrophages has no apparent effect, in vascular cells NOD1 activation results in the profound induction of NOSII and shock in vivo (Cartwright et al. 2007). NOD2 is thought to be important in the maintenance of a healthy gut barrier since individuals who carry a defective NOD2 because of a polymorphism have an increased risk of Crohn's disease (Murillo et al. 2003, Abreu et al. 2005) or other intestinal disorders presumably because the lack of NOD2 compromises gut barrier function to bacteria.

\section{PRRs and sensing of whole bacteria}

While it is clear that TLR4 is the receptor for LPS and TLR2 for LTA, we should remember that whole bacteria contain a 


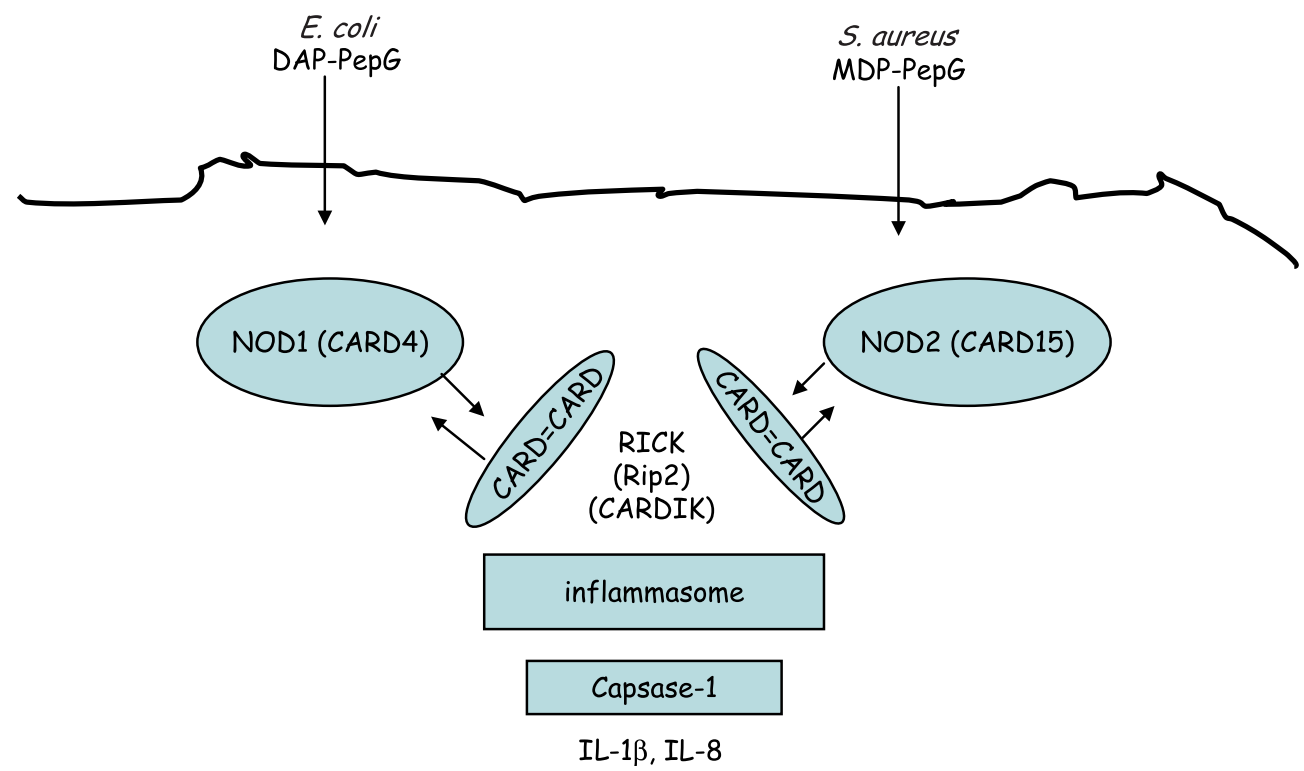

Figure 3 Signalling pathways associated with NOD1 and NOD2. Nucleotide oligomerisation domain (NOD)-1 or NOD2 are cytosolic proteins also known as CARD4 and CARD15 respectively. The CARD domains on NOD1 or NOD2 interact with CARD domains on RICK (also known as Rip2 or CARDIK) to form a signalling platform - the inflammasome that signals via caspase-1 resulting in the induction of IL-1 $\beta$ and IL-8.

number of different PAMPs each of which activate different PRRs. Gram-negative bacteria have LPS, PepG, DNA and flagellin (for motile forms). Gram-positive bacteria have LTA, lipoproteins, DNA or flagellin. Clearly in the complex setting of a pathogen infection, a number of PRR pathways will be activated. The picture is likely to be even more complex in the case of polymicrobial infections. There is considerable cross talk between TLRs and between the TLR-NOD pathways. In macrophages, ligands for TLR2/1 or TLR2/6 synergise with ligands for TLR 4 to induce NOSII or TNF $\alpha$ (Vogel et al. 2003, Paul-Clark et al. 2006). Similarly, co-stimulation of NOD and TLR receptors results in amplification loops in some cells (Akira \& Takeda 2004, Strober et al. 2006). Some studies have investigated which of the possible PRRs would predominate in the sensing of whole pathogens.

\section{Viral PRRs}

TLR3, TLR7 and TLR8 are intracellular TLRs that are activated by viral PAMPs mediating host immune responses. TLR3 recognises double-stranded RNA (Alexopoulou et al. 2001), while TLR7 (Diebold et al. 2004) and TLR8 (Heil et al. 2004) recognise single-stranded RNA. As mentioned above, TLR 3 recruits TRIF only while TLR7 and TLR 8 recruits MyD88. Importantly, TLR7 and TLR 8 have become important therapeutic targets for the treatment of some specific diseases. Agonists of TLR7, including imiquimod (an imidazoquinoline), cure genital warts caused by human papilloma virus infections (Mitchell et al. 2006). Agonists for TLR7 are successful treatments for neoplastic skin lesion basal cell carcinoma (Stockfleth et al. 2003), metastatic melanoma and other cancers (Mitchell et al. 2006).

\section{Non-pathogenic ligands for TLR receptors}

The discovery of TLRs and NLRs has increased our understanding of innate immunity exponentially. However, what is also interesting is the emergence of evidence implicating TLRs and NODs in the pathogenesis of diseases not previously associated with a pathogen element such as atherosclerosis (Bjorkbacka et al. 2004, Michelsen et al. 2004) and asthma (Chaudhuri et al. 2005, Feleszko et al. 2006). Although it is not possible to rule out a role of infection in such disease, it is increasingly recognised that host-derived signals activate TLRs (Mullick et al. 2005). Examples of endogenous ligands of TLRs are heat shock proteins, hyaluronic acid fragments, soluble heparan sulphate, fibrinogen extra domain $\mathrm{A}$, oxidised LDL and $\beta$-defensin 2 (Tobias $\&$ Curtiss 2005). Work from our own group also suggests that oxidant stress is sensed by TLR2-dependent pathways (Paul-Clarke et al. 2005; http://www.pa2online.org/ abstracts/Vol3Issue2.abst159P.pdf). Clearly this observation opens up a central role for TLRs in the wider setting of human disease.

\section{The role of TLRs in the immune-adrenal cross talk}

There is an interesting emerging area of research showing a cross talk between TLR and adrenal pathways (Bornstein 
et al. 2006). It has been known for some time that desensitisation to LPS in vivo is mediated by adrenal hormones (Szabo et al. 1994). TLR2 and TLR4 are expressed in the adrenals and PAMPs such as LPS stimulate glucocorticoid release. Glucocorticoids, in turn, inhibit many actions of LPS in gene induction in cells (Buckingham et al. 2006). TLR2 (Bornstein et al. 2004) and TLR4 (Zacharowski et al. 2006) are directly implicated in the link between bacterial cell wall PAMPs and appropriate adrenal stress response.

\section{Concluding remarks}

As we progressively understand more about how different tissues in the body sense pathogens, we anticipate new therapeutic targets will be revealed. This is not only important when we consider diseases caused or exacerbated by pathogens, but also for diseases that are mediated by these pathways via endogenous ligands and with no apparent pathogenic cause.

\section{Acknowledgements}

The authors declare that there is no conflict of interest that would prejudice the impartiality of this scientific work.

\section{References}

Abreu MT, Fukata M \& Arditi M 2005 TLR signaling in the gut in health and disease. Journal of Immunology 174 4453-4460.

Ajuebor MN, Das AM, Virag L, Flower RJ, Szabo C \& Perretti M 1999 Role of resident peritoneal macrophages and mast cells in chemokine production and neutrophil migration in acute inflammation: evidence for an inhibitory loop involving endogenous IL-10. Journal of Immunology $\mathbf{1 6 2}$ $1685-1691$

Akira S \& Takeda K 2004 Toll-like receptor signalling. Nature Reviews. Immunology 4 499-511.

Alexopoulou L, Holt AC, Medzhitov R \& Flavell RA 2001 Recognition of double-stranded RNA and activation of NF-kappaB by Toll-like receptor 3. Nature $413732-738$

Anderson KV, Bokla L \& Nusslein-Volhard C 1985 Establishment of dorsalventral polarity in the Drosophila embryo: the induction of polarity by the Toll gene product. Cell 42 791-798.

Belvin MP \& Anderson KV 1996 A conserved signaling pathway: the Drosophila Toll-dorsal pathway. Annual Review of Cell and Developmental Biology 12 393-416.

Bishop-Bailey D, Larkin SW, Warner TD, Chen G \& Mitchell JA 1997 Characterization of the induction of nitric oxide synthase and cyclooxygenase in rat aorta in organ culture. British Journal of Pharmacology 121 125-133.

Bjorkbacka H, Kunjathoor VV, Moore KJ, Koehn S, Ordija CM, Lee MA, Means T, Halmen K, Luster AD, Golenbock DT et al. 2004 Reduced atherosclerosis in MyD88-null mice links elevated serum cholesterol levels to activation of innate immunity signaling pathways. Nature Medicine $\mathbf{1 0}$ 416-421.

Bornstein SR, Zacharowski P, Schumann RR, Barthel A, Tran N, Papewalis C, Rettori V, McCann SM, Schulze-Osthoff K, Scherbaum WA et al. 2004 Impaired adrenal stress response in Toll-like receptor 2-deficient mice. PNAS $10116695-16700$.
Bornstein SR, Ziegler CG, Krug AW, Kanczkowski W, Rettori V, McCann SM, Wirth M \& Zacharowski K 2006 The role of Toll-like receptors in the immune-adrenal crosstalk. Annals of the New York Academy of Sciences 1088 307-318.

Buckingham JC, John CD, Solito E, Tierney T, Flower RJ, Christian H \& Morris J 2006 Annexin 1, glucocorticoids, and the neuroendocrineimmune interface. Annals of the New York Academy of Sciences 1088 396-409.

Cartwright N, Murch O, McMaster SK, Paul-Clark MJ, van Heel DA, Ryffel B, Quesniaux VF, Evans TW, Thiemermann C \& Mitchell JA 2007 Selective NOD1 agonists cause shock and organ injury/dysfunction in vivo. American Journal of Respiratory and Critical Care Medicine 175 595-603.

Chamaillard M, Hashimoto M, Horie Y, Masumoto J, Qiu S, Saab L, Ogura Y, Kawasaki A, Fukase K, Kusumoto S et al. 2003 An essential role for NOD1 in host recognition of bacterial peptidoglycan containing diaminopimelic acid. Nature Immunology 4 702-707.

Chaudhuri N, Dower SK, Whyte MK \& Sabroe I 2005 Toll-like receptors and chronic lung disease. Clinical Science 109 125-133.

Cunha JM, Cunha FQ, Poole S \& Ferreira SH 2000 Cytokine-mediated inflammatory hyperalgesia limited by interleukin-1 receptor antagonist. British Journal of Pharmacology 130 1418-1424.

Diebold SS, Kaisho T, Hemmi H, Akira S \& Reis e Sousa C 2004 Innate antiviral responses by means of TLR7-mediated recognition of singlestranded RNA. Science 303 1529-1531.

Elmali N, Baysal O, Harma A, Esenkaya I \& Mizrak B 2007 Effects of resveratrol in inflammatory arthritis. Inflammation 30 1-6.

Feleszko W, Jaworska J \& Hamelmann E 2006 Toll-like receptors-novel targets in allergic airway disease (probiotics, friends and relatives). European Journal of Pharmacology $\mathbf{5 3 3}$ 308-318.

Fitzgerald KA, Rowe DC \& Golenbock DT 2004 Endotoxin recognition and signal transduction by the TLR4/MD2-complex. Microbes and Infection $\mathbf{6}$ 1361-1367.

Gay NJ \& Keith FJ 1991 Drosophila Toll and IL-1 receptor. Nature 351 355-356.

Gewirtz AT, Navas TA, Lyons S, Godowski PJ \& Madara JL 2001 Cutting edge: bacterial flagellin activates basolaterally expressed TLR 5 to induce epithelial proinflammatory gene expression. Journal of Immunology 167 1882-1885.

Haddad E, McCluskie K, Birrell MA, Dabrowski D, Pecoraro M, Underwood S, Chen B, De Sanctis GT, Webber SE, Foster ML et al. 2002 Differential effects of ebselen on neutrophil recruitment, chemokine, and inflammatory mediator expression in a rat model of lipopolysaccharide-induced pulmonary inflammation. Journal of Immunology 169 974-982.

Hayashi F, Smith KD, Ozinsky A, Hawn TR, Yi EC, Goodlett DR, Eng JK, Akira S, Underhill DM \& Aderem A 2001 The innate immune response to bacterial flagellin is mediated by Toll-like receptor 5. Nature $\mathbf{4 1 0}$ 1099-1103.

van Heel DA, Ghosh S, Butler M, Hunt K, Foxwell BM, Mengin-Lecreulx D \& Playford RJ 2005 Synergistic enhancement of Toll-like receptor responses by NOD1 activation. European Journal of Immunology 35 2471-2476.

Heil F, Hemmi H, Hochrein H, Ampenberger F, Kirschning C, Akira S, Lipford G, Wagner H \& Bauer S 2004 Species-specific recognition of single-stranded RNA via Toll-like receptor 7 and 8. Science 303 1526-1529.

Hemmi H, Takeuchi O, Kawai T, Kaisho T, Sato S, Sanjo H, Matsumoto M, Hoshino K, Wagner H, Takeda K et al. 2000 A Toll-like receptor recognizes bacterial DNA. Nature 408 740-745.

Hoebe K, Georgel P, Rutschmann S, Du X, Mudd S, Crozat K, Sovath S, Shamel L, Hartung T, Zahringer U et al. 2005 CD36 is a sensor of diacylglycerides. Nature $\mathbf{4 3 3}$ 523-527.

Hoshino K, Takeuchi O, Kawai T, Sanjo H, Ogawa T, Takeda Y, Takeda K \& Akira S 1999 Cutting edge: Toll-like receptor 4 (TLR4)-deficient mice are hyporesponsive to lipopolysaccharide: evidence for TLR 4 as the Lps gene product. Journal of Immunology 162 3749-3752.

Imler JL \& Hoffmann JA 2001 Toll receptors in innate immunity. Trends in Cell Biology 11 304-311. 
Inohara N, Ogura Y, Fontalba A, Gutierrez O, Pons F, Crespo J, Fukase K, Inamura S, Kusumoto S, Hashimoto M et al. 2003 Host recognition of bacterial muramyl dipeptide mediated through NOD2. Implications for Crohn's disease. Journal of Biological Chemistry 278 5509-5512.

Inohara N, Chamaillard M, McDonald C \& Nunez G 2005 NOD-LRR proteins: role in host-microbial interactions and inflammatory disease. Annual Review of Biochemistry 74 355-383.

Kengatharan KM, De Kimpe SJ \& Thiemermann C 1996a Role of nitric oxide in the circulatory failure and organ injury in a rodent model of Grampositive shock. British Journal of Pharmacology 119 1411-1421.

Kengatharan M, De Kimpe SJ \& Thiemermann C 19966 Analysis of the signal transduction in the induction of nitric oxide synthase by lipoteichoic acid in macrophages. British Journal of Pharmacology 117 1163-1170.

Lemaitre B, Nicolas E, Michaut L, Reichhart JM \& Hoffmann JA 1996 The dorsoventral regulatory gene cassette spatzle/Toll/cactus controls the potent antifungal response in Drosophila adults. Cell 86 973-983.

Lonchampt MO, Auguet M, Delaflotte S, Goulin-Schulz J, Chabrier PE \& Braquet P 1992 Lipoteichoic acid: a new inducer of nitric oxide synthase. Journal of Cardiovascular Pharmacology 20 (Suppl 12) S145-S147.

Maclean LD \& Weil MH 1956 Hypotension (shock) in dogs produced by Escherichia coli endotoxin. Circulation Research 4 546-556.

Mansell A, Brint E, Gould JA, O'Neill LA \& Hertzog PJ 2004 Mal interacts with tumor necrosis factor receptor-associated factor (TRAF)-6 to mediate NF-kappaB activation by Toll-like receptor (TLR)-2 and TLR4. Journal of Biological Chemistry 279 37227-37230.

Marchalant Y, Rosi S \& Wenk GL 2007 Anti-inflammatory property of the cannabinoid agonist WIN-55212-2 in a rodent model of chronic brain inflammation. Neuroscience 144 1516-1522.

Mariathasan S \& Monack DM 2007 Inflammasome adaptors and sensors: intracellular regulators of infection and inflammation. Nature Reviews. Immunology 7 31-40.

Masumoto J, Yang K, Varambally S, Hasegawa M, Tomlins SA, Qiu S, Fujimoto Y, Kawasaki A, Foster SJ, Horie Y et al. 2006 Nod1 acts as an intracellular receptor to stimulate chemokine production and neutrophil recruitment in vivo. Journal of Experimental Medicine 203 203-213.

Medzhitov R, Preston-Hurlburt P \& Janeway CA Jr 1997 A human homologue of the Drosophila Toll protein signals activation of adaptive immunity. Nature 388 394-397.

Michelsen KS, Doherty TM, Shah PK \& Arditi M 2004 TLR signaling: an emerging bridge from innate immunity to atherogenesis. Journal of Immunology 173 5901-5907.

Mitchell JA, Fitzgerald KA, Coyle A, Silverman N \& Cartwright N 2006 TOLLing away in Brazil. Nature Immunology 7 675-679.

Mullick AE, Tobias PS \& Curtiss LK 2005 Modulation of atherosclerosis in mice by Toll-like receptor 2. Journal of Clinical Investigation $\mathbf{1 1 5}$ 3149-3156.

Murillo LS, Morre SA \& Pena AS 2003 Role of the CARD15 gene in the pathogenesis of Crohn disease: phenotypic classification and prognostic implications. Scandinavian Journal of Gastroenterology 38 1107-1114.

Ozinsky A, Underhill DM, Fontenot JD, Hajjar AM, Smith KD, Wilson CB, Schroeder L \& Aderem A 2000 The repertoire for pattern recognition of pathogens by the innate immune system is defined by cooperation between Toll-like receptors. PNAS 97 13766-13771.

Paul-Clark MJ, McMaster SK, Belcher E, Sorrentino R, Anandarajah J, Fleet M, Sriskandan S \& Mitchell JA 2006 Differential effects of Gram-positive versus Gram-negative bacteria on NOSII and TNFalpha in macrophages: role of TLRs in synergy between the two. British Journal of Pharmacology $\mathbf{1 4 8}$ 1067-1075.

Poltorak A, He X, Smirnova I, Liu MY, Van Huffel C, Du X, Birdwell D, Alejos E, Silva M, Galanos C et al. 1998 Defective LPS signaling in $\mathrm{C} 3 \mathrm{H} / \mathrm{HeJ}$ and $\mathrm{C} 57 \mathrm{BL} / 10 \mathrm{ScCr}$ mice: mutations in Tlr4 gene. Science $\mathbf{2 8 2}$ 2085-2088.

Rock FL, Hardiman G, Timans JC, Kastelein RA \& Bazan JF 1998 A family of human receptors structurally related to Drosophila Toll. PNAS 95 $588-593$.

Schromm AB, Lien E, Henneke P, Chow JC, Yoshimura A, Heine H, Latz E, Monks BG, Schwartz DA, Miyake K et al. 2001 Molecular genetic analysis of an endotoxin nonresponder mutant cell line: a point mutation in a conserved region of MD-2 abolishes endotoxin-induced signaling. Journal of Experimental Medicine 194 79-88.

Schumann RR, Leong SR, Flaggs GW, Gray PW, Wright SD, Mathison JC, Tobias PS \& Ulevitch RJ 1990 Structure and function of lipopolysaccharide binding protein. Science 249 1429-1431.

Schwandner R, Dziarski R, Wesche H, Rothe M \& Kirschning CJ 1999 Peptidoglycan- and lipoteichoic acid-induced cell activation is mediated by Toll-like receptor 2. Journal of Biological Chemistry 274 17406-17409.

Shimazu R, Akashi S, Ogata H, Nagai Y, Fukudome K, Miyake K \& Kimoto M 1999 MD-2, a molecule that confers lipopolysaccharide responsiveness on Toll-like receptor 4. Journal of Experimental Medicine 189 $1777-1782$.

Skidmore BJ, Chiller JM, Morrison DC \& Weigle WO 1975 Immunologic properties of bacterial lipopolysaccharide (LPS): correlation between the mitogenic, adjuvant, and immunogenic activities. Journal of Immunology $\mathbf{1 1 4}$ $770-775$.

Stockfleth E, Trefzer U, Garcia-Bartels C, Wegner T, Schmook T \& Sterry W 2003 The use of Toll-like receptor-7 agonist in the treatment of basal cell carcinoma: an overview. British Journal of Dermatology 149 (Suppl 66) 53-56.

Strober W, Murray PJ, Kitani A \& Watanabe T 2006 Signalling pathways and molecular interactions of NOD1 and NOD2. Nature Reviews. Immunology 6 9-20.

Szabo C, Mitchell JA, Thiemermann C \& Vane JR 1993 Nitric oxidemediated hyporeactivity to noradrenaline precedes the induction of nitric oxide synthase in endotoxin shock. British Journal of Pharmacology 108 786-792.

Szabo C, Thiemermann C, Wu CC, Perretti M \& Vane JR 1994 Attenuation of the induction of nitric oxide synthase by endogenous glucocorticoids accounts for endotoxin tolerance in vivo. PNAS 91 271-275.

Taguchi T, Mitcham JL, Dower SK, Sims JE \& Testa JR 1996 Chromosomal localization of TIL, a gene encoding a protein related to the Drosophila transmembrane receptor Toll, to human chromosome $4 \mathrm{p} 14$. Genomics 32 486-488.

Takada H \& Uehara A 2006 Enhancement of TLR-mediated innate immune responses by peptidoglycans through NOD signaling. Current Pharmaceutical Design 12 4163-4172.

Takeuchi O, Hoshino K, Kawai T, Sanjo H, Takada H, Ogawa T, Takeda K \& Akira S 1999a Differential roles of TLR2 and TLR4 in recognition of Gram-negative and Gram-positive bacterial cell wall components. Immunity 11 443-451.

Takeuchi O, Kawai T, Sanjo H, Copeland NG, Gilbert DJ, Jenkins NA, Takeda K \& Akira S 1999b TLR6: a novel member of an expanding Tolllike receptor family. Gene 231 59-65.

Takeuchi O, Kawai T, Muhlradt PF, Morr M, Radolf JD, Zychlinsky A, Takeda K \& Akira S 2001 Discrimination of bacterial lipoproteins by Tolllike receptor 6. International Immunology 13 933-940.

Takeuchi O, Sato S, Horiuchi T, Hoshino K, Takeda K, Dong Z, Modlin RL \& Akira S 2002 Cutting edge: role of Toll-like receptor 1 in mediating immune response to microbial lipoproteins. Journal of Immunology 169 $10-14$.

Tobias P \& Curtiss LK 2005 Thematic review series: the immune system and atherogenesis. Paying the price for pathogen protection: Toll receptors in atherogenesis. Journal of Lipid Research 46 404-411.

Tobias PS, Soldau K \& Ulevitch RJ 1986 Isolation of a lipopolysaccharide binding acute phase reactant from rabbit serum. Journal of Experimental Medicine 164 773-793.

Toshchakov V, Jones BW, Perera PY, Thomas K, Cody MJ, Zhang S, Williams BR, Major J, Hamilton TA, Fenton MJ et al. 2002 TLR4, but not TLR2, mediates IFN-beta-induced STAT1alpha/beta-dependent gene expression in macrophages. Nature Immunology 3 392-398.

Travassos LH, Girardin SE, Philpott DJ, Blanot D, Nahori MA, Werts C \& Boneca IG 2004 Toll-like receptor 2-dependent bacterial sensing does not occur via peptidoglycan recognition. EMBO Reports 5 1000-1006.

Triantafilou M, Gamper FG, Haston RM, Mouratis MA, Morath S, Hartung T \& Triantafilou K 2006 Membrane sorting of Toll-like receptor (TLR)-2/6 and 
TLR2/1 heterodimers at the cell surface determines heterotypic associations with CD36 and intracellular targeting. Journal of Biological Chemistry 281 31002-31011.

Visintin A, Mazzoni A, Spitzer JA \& Segal DM 2001 Secreted MD-2 is a large polymeric protein that efficiently confers lipopolysaccharide sensitivity to Toll-like receptor 4. PNAS 98 12156-12161.

Vogel SN, Fitzgerald KA \& Fenton MJ 2003 TLRs: differential adapter utilization by Toll-like receptors mediates TLR-specific patterns of gene expression. Molecular Interventions 3 466-477.

West AP, Koblansky AA \& Ghosh S 2006 Recognition and signaling by Toll-like receptors. Annual Review of Cell and Developmental Biology 22 409-437.

Wright SD, Ramos RA, Tobias PS, Ulevitch RJ \& Mathison JC 1990 CD14, a receptor for complexes of lipopolysaccharide (LPS) and LPS binding protein. Science 249 1431-1433.
Zacharowski K, Zacharowski PA, Koch A, Baban A, Tran N, Berkels R, Papewalis C, Schulze-Osthoff K, Knuefermann P, Zahringer U et al. 2006 Toll-like receptor 4 plays a crucial role in the immune-adrenal response to systemic inflammatory response syndrome. PNAS 103 6392-6397.

Zweigner J, Schumann RR \& Weber JR 2006 The role of lipopolysaccharidebinding protein in modulating the innate immune response. Microbes and Infection 8 946-952.

Received 8 February 2007

Accepted 2 April 2007

Made available online as an Accepted Preprint 3 April 2007 